\title{
How To Choose Suitable English Coursebooks To Be Used \\ In The English Teaching-Learning Process: Doing $A$ \\ Micro Evaluation
}

\author{
Kharis Sukarno Muhammad \\ State University of Yogyakarta
}

\begin{abstract}
English coursebooks are one of the main elements determining the success of the English teaching-leaming process to meet the pre-determined objectives. Currently, the teachers of. English in Indonesia face a complicated tasks in choosing suitable English teaching materials in the form of English coursebooks. The purpose of the article is to discuss an appropriate way to choose English coursebooks suitable with the students' socio-economic cultural backgrounds to facilitate students' learning. The intended way is that the teachers of English do an empirical evaluation of the coursebooks they are using, a retrospective evaluation. The evaluation can be done through either macro or micro evaluation. The tangible and practical evaluation to do is a micro evaluation in which the teachers of English retrospectively and thoroughly evaluate certain parts of the English coursebooks representing the whole content. The criteria to valuate include goals, students' backgrounds (topics and vocabulary related to students' lives), cultural acceptability, language skills to develop, quality of practical materials in the classroom (activating students' participation), roles, sequencing of the materials (procedure), formats, instructions, and visualization. If the teachers of English find out such English coursebooks through their evaluation, they can use the coursebooks in the following terms. It a wise way to choose English coursebooks to be used to optimally reach the pre-determined objectices. If the teachers of English do not find such suitable English coursebooks through their evaluation, they can add materials to or reduce the content of the coursebooks and finally they will have teachers' edition English teaching materials.
\end{abstract}

Keywords: suitable English coursebooks, English teaching-learning process, retrospective evaluation, macro evaluation, and micro evaluation 


\section{A. Introduction}

One of the main components determining the success of the English teaching-learning process is English coursebooks. They consist of a set of English teaching materials so called a set of tasks. Teaching materials are a key component in most language programs, including in schools. Whether the teachers of English use a textbook or other forms of materials, instructional materials generally serve as the basis for much of the language input learners receive and the language practice occurring in the classroom, more prominent than any other element in the curriculum. To reach the objectives of the English teaching-learning process, therefore, the English teaching materials must be suitable with the teachers of English, students, and environments. It is in line with the implementation of school-based curriculum which insists that the materials be based on students' socio-economic cultural backgrounds.

Recently, to reach the objectives of the English teaching-leaming process, as others, the government of the Republic of Indonesia through Ministry of National Education and private publishers provide the teachers of English with various teaching materials or tasks in the form of English coursebooks. Those English coursebooks consisting of a set of English teaching materials have been predictively evaluated by the experts on the basis of philosophical perspectives or have been developed on the basis of theories of learning, not retrospectively evaluated on the basis of empirical evidence in the classroom during the teachinglearning process.

The quality of those English coursebooks is theoretically good but empirically they might be suitable with the English teachers, students, and environments or might be not, because of the implementation of school-based curriculum. As a result, the teachers of English in Indonesia face the task of choosing what English teaching materials to use, whether suitable with their students' backgrounds or not. To find out teaching materials in the form of English coursebooks suitable with the students' backgrounds, therefore, it is wise that the English teachers retrospectively evaluate English coursebooks having been being used, and possibly to be used in the following terms. 


\section{B. English Coursebooks}

English coursebooks consisting of English teaching materials in the form of tasks provide the students with meaningful inputs for their comprehension of a certain goal to achieve, as stated in the standard of content of English. Therefore, English coursebooks are one of the main elements determining the success of the English teaching-learning process. The writer's point of view is in accordance with Richards and Renandya (2002) and Nunan's ideas (1999) as follows.

Teaching materials are a key component in most language programs. Whether the teacher uses a textbook, institutionally prepared materials, or makes use of his or her own materials, instructional materials generally serve as the basis for much of the language input learners receive and the language practice that occurs in the classroom. (Richards and Renandya, 2002: 65-66)

At the classroom level; materials often seem more prominent than any other element in the curriculum. They are the tangible manifestation of the curriculum in action. They are, in fact, omnipresent in the language classroom and it is difficult to imagine a class without books, pictures, filmstrips, realia, games and soon. (Nunan, 1999: 98)

Both experts above emphasize that any form of teaching materials are a key component in language programs. One of them is presented in the form of textbooks, or narrowly called couresebooks. Nunan, in other words, states that teaching materiais coursebooks are the representation of the curriculum, currently in Indonesia it is called standard of content consisting of standard of competence and bz sic competence (Depdiknas, 2006). Nunan (1999: 98), furthermore, states that materials do more than simply lubricate the wheels of learning. Good materials also provide models for teachers to follow in developing their own materials. Richards (2001:15) adds that the primary input learners received to the language learning is the textbook.

Coursebooks are prepackaged, published books used by the students and teacher as the primary basis for a language course. Coursebooks range from those that are broadly focus on developing all language skills to those that focus on a specific skill such as writing, or specific area such as hotel management (Graves in Nunan, 2003: 226).

Ansary and Babaii (2002) ask how necessary a textbook is. The answer to this question depends on the teachers' own teaching style, the resources available 
to them, the accepted standards of teaching in every language school, etc. Brown (2001: 136), furthermore, states that the most obvious and most common form of material support for language instruction comes through textbooks. Even though the teachers may have idealistic thoughts about other (and better) textbooks, their challenge is to make the very best use of the textbooks they have (Brown, 2001: 136-137). Therefore, it is wise that the English teachers choose suitable English coursebooks through a retrospective evaluation during the teaching-learning process.

The English language teaching (ELT) experts' statements above emphasize that English coursebooks have a vital role as one of the factors determining the success of English language teaching-learning process. The teachers of English can adopt or adapt the English teaching materials presented in a series of tasks in a coursebook. If there is a teacher's edition book, the teachers will easily use the book. However, if there is no teacher's edition, the teachers' task becomes one of devising ways to present the content and the exercises of the textbook to the students (Brown, 2001: 137). Therefore, if it is available for the teachers to choose a textbook/coursebook, the teachers have an exciting but complex task ahead of them (Brown, 2001: 141). It is in accordance with Ellis' statement (1997: 36) that teachers are often faced with the task of choosing what teaching materials to use.

Using teaching materials, possibly in the form coursebooks, will give benefit to both the teacher and the students as stated by Wright as follows.

We teach with, rather than through, materials, thus being free to improvise and adapt in response to leamer feedback. Effective teaching materials, by providing cultural and linguistic input and a rich selection of integrated activities, are thus a professional tool which can actually assist teachers to be more responsive, both by leaving them time to cater to individual needs and by expanding their teaching repertoire. Learners, too, can benefit from access to the materials used in class, and the control and structure this allows them to put on their learning. (Wright in Crawford, 2002: 88)

It means that materials facilitate teaching and leaming in the classroom. However, the intended materials should provide the students with cultural and linguistic inputs. The term 'cultural inputs' refers to students' socio-economic cultural background environments. This is in accordance with Act No. 20, 2003 about National Education System articles 1 and 36, Government Rule No. 19, 2005 
about national standard of education, and National Education Ministerial Rule No. 22 (about standard of content), 23 (about standard of graduate's competencies), and 24, about the implementation of National Ministerial rules No. 22 and 23) (2006).

\section{Tasks}

English coursebooks consist of English teaching materials in the form of tasks. A task can be described in terms of its objectives, input, conditions, procedures, and outcomes. The properties of the task should simultaneously be presented so that they can give the learners learning experiences involving linguistic competence and linguistic performance. Linguistic performance is closely related to communicative competence, i.e., the knowledge that users of a language have internalized to enable them to understand and produce messages in the language. It entails linguistic competence, pragmatic competence (Ellis, 2003: 696), and sociolinguistic competence (Council of Europe, 2002: 108). Pragmatic competence refers to the knowledge that speaker-hearer use in order to engage in communication (Ellis, 2003: 719).

The objectives of the task refer to what skills that the learners should accomplish. The input of the task provides the students with activities and exercises to work on (i.e. the verbal or non-verbal information supplied). The conditions of the task refer to under which the task is to be performed (e.g. whether in lockstep with the whole class or in small group work). The procedures of the task refer to what the students need to carry out to complete the task (e.g., whether the students have the opportunity to plan prior to performing the task). The last property of the task is outcomes. Outcomes refer to what is achieved on completion of the task.

The outcomes take the form of the product(s) and processes. Products refer to what the students will accomplish (e.g. drawing a map, a written paragraph, some kind of decision). The processes refer to what the students will be engaged in performing the task (e.g. negotiating meaning when some communication problem arises, correcting other students' errors, asking questions to extend a topic) (Ellis, 1997: 38).

According to Breen in Nunan (2004: 3), pedagogically, task is any structural language learning endeavour which has a particular objectives, 
appropriate content, a specific working procidure, and a range of outcomes for those who undertake the task. Task is therefore assumed to refer to a range of workplans which have the overall purposes of facilitating language learning from the simple and brief exercise type, to more complex and lengthy activities such as group problem-solving or simulations and decision-making.

The tasks used in the English teaching-learning process are aimed at developing students' communicative competence. Communicative pedagogic tasks, therefore, aim to actively involve learners in meaning ful communication, are relevant, are challenging but feasible (with task manipulation where possible), and have identifiable outcomes. The learners are involved for contributions to task selection, management, and evaluation, which in a language learning context may often become integral parts of the tasks themselves. Classroom tasks, whether reflecting 'real-life' use or essentially 'pedagogic' in nature, are communicative to the extent that they require learners to comprehend, negotiate, and express meaning in order to achieve a communicative goal (Council of Europe, 2002: I58).

On the basis of the ELT experts'views on tasks, the writer concludes that tasks are workplans consisting of a series of activities and exercises that the students should accomplish to achieve communicative competence. Therefore, they have goals, inputs, procedures, and outcomes. If the students are able to accomplish the overall tasks suitable with their socio-economic cultural backgrounds, they will be able to develop their four language skills and are able to communicate intelligibly relevant to their lives.

\section{Evaluation of English coursebooks (tasks)}

Teachers are often faced with the task of choosing what teaching materials to use (Ellis, 1997: 36). It also happens in Indonesia in which the government through National Education Department and private publishers provide the teachers with abundant teaching materials in the form tasks. However, the teaching materials provided, including English teaching materials in the form of tasks presented in English course-books, are not always suitable with the teachers, students, and environments where the English teaching learning process takes place. 
The fact in Indonesia above is in line with Ansary \& Babaii's statement (2002). They state that teachers, students, and administers are all consumers of textbooks. All these groups, of course, may have conflicting views about what a good/standard textbook is. However, the question is where they can turn to for reliable advice on how to make an informed decision and select a suitable textbook. Furthermore, Murphy (1993: 146) proposes questions related to the use of tasks in the classroom. He asks, "How do teacher and learner decide which task to proceed next? What do teacher and learner identify as a task? How does the teacher know whether a task suited the learner, that is to say, interested them and was, in their view, controllable? He answers his questions by himself. The answer is a formative evaluation through a process, teaching-learning process in the classroom. Johnson, $\mathrm{Kim}$, and Ya-Fang et al. (2008: 157) state that in the last several years the number of English-language teaching materials on the market has grown exponentially, addressing a variety of learner interests, skill levels, and tastes. Among other features, these materials also vary in their linguistic design, focus, and objectives, making the choice of a textbook an integral part of many ELT classrooms a seemingly formidable task.

In relation to a number of coursebooks provided by the government and private publishers, Ansary and Babaii (2002) state that there is no perfect textbook. Therefore, teachers should have the option of assigning supplementary materials based on their own specific needs in their own specific teaching situation. Therefore, it is suggested that the teachers adapt the teaching materials provided to be suitable with their students. Even they need to do an empirical evaluation of such a teaching material or task when they are using it in the teaching-learning process. In short, the abundant teaching materials, including English teaching materials in the form of tasks need to be empirically evaluated.

The first way in which materials may be evaluated is in terms of how well they reflect the principles by which they have been written. Theoretically, in Indonesia they must be based on the standard of content (Education Ministerial Rule No. 22, year 2006). In the case of class textbooks, the evaluation criteria will be those used when deciding which book is best for the teaching context (ReaDickins and Germaine, 2003: 256). Byrd in Celce-Muria (2001: 416) states that systems for evaluation of textbooks (and other instructional materials) generally provide checklists built around numerous aspects of teaching and student-teacher interactions. 
The principal problem is that some aspects in the framework actually entail coming to a conclusion about other aspects in the framework. This means that in building up an analysis of a set of materials, teacher-analysts will not only have to examine different sections of the materials but, more importantly, move through different 'level' of analysis, making more and more inferences - and subjective judgments as they move from a consideration of the more easily identifiable aspects to the more abstract and complex (Littlejohn in Tomlinson, 1998: 195). In line with the experts' perspectives on teaching material above, Murphy in Crookes and Gass (1993: 145-146) states that the idea of teachers conducting investigations into what is happening in their classroom, like many of the ideas about tasks, has been around for some time, but has come into greater prominence as educators realize that change has to take place in the school through teachers.

The writer agrees with the statements above that the English teaching materials presented in English coursebooks should be empirically evaluated. The teachers of English are the persons who exactly know what happens in the classroom during the English teaching-learning process. Therefore, the teachers of English must be a part of the research empirically evaluating the English couresebooks.

\section{Predictive evaluation}

A predictive evaluation of coursebooks is an evaluation which is designed to make a decision regarding what materials to use in the classroom, during the teaching-learning process (Ellis, 1997: 36). It is done on the basis of theories on a certain subject matter, theories of leaming, and theories of psychology. Therefore, teaching materials written by experts are expected to be suitable with the students and to facilitate students' learning.

A predictive evaluation of English coursebooks is conducted behind a desk. It is done before the books are massively produced. Theoretically the coursebooks predictively evaluated will suit the teachers and students' needs in learning. It is the opposite of retrospective evaluation that is conducted in the fields, classroom.

In Indonesia, predictive evaluation of English coursebooks is conducted by Badan Standar Nasional Pendidikan (BSNP), Board of Educational National Standard. The instrument of English coursebooks predictive evaluation consists of content suitability and delivery suitability. Content 
suitability consists of (1) appropriateness between content and standard of . competence and basic competence, (2) material accuracy, and (3) supporting materials. Delivery suitability consists of $(I)$ presentation technique, (2) presentation of learning, and (3) completeness of presentation.

2. Retrospective evaluation

$A$ retrospective evaluation of coursebooks is designed to examine materials that have actually been used in the classroom. Retrospective evaluations can be impressionistic or empirical (Ellis, 1997: 36): It is in line with Harmer (2001: 301) that states that coursebook evaluation is a judgment on how well a book has performed in fact. It means that retrospective evaluation can refer to empirical evaluation of teaching materials done during the teaching-learning process.

The needs to evaluate materials retrospectively take on special importance. Such an evaluation provides the teacher with information which can be used to determine whether it is worthwhile using the materials again, which activities 'work' and which do not, and how to modify the materials to make them more effective for future use. It is what happens in the classroom when the teaching materials are used (Ellis, 1997: 37).

The purpose of carrying out the evaluation is for accountability and development of the task. Where accountability is at stake, the purpose of the evaluation is to determine whether the stated goals of the program have been met. Where at development, the purpose of the evaluation is to improve the curriculum and/or to foster teacher development (Ellis, 1998: 223).

Empirical evaluation of the teaching materials can be conducted through either macro-evaluation or micro-evaluation. It is done during and after the teaching-learning process. The difference is the number of teaching materials or tasks that are empirically evaluated.

a. Macro-evaluation

Empirical macro-evaluation is a kind of evaluation which empirically evaluate the whole teaching materials or tasks used in the classroom, during the teaching-learning process. A macro evaluation is an evaluation carried out for accountability and/or developmental 
purposes by collecting information relating to various administrative and curricular aspects of the program (Ellis, 1998: 218).

The empirical macro-evaluation of coursebooks means to evaluate the whole content of the coursebooks in the classroom. It is time consuming because it scrutinizes each elements of the coursebooks. Therefore, it needs longer time to collect and analyze data. It also needs more energy and a lot of operating costs. It is hard to do the whole evaluation of the coursebooks because the teachers are more concerned whether they are able to accomplish the goals or not, they more focus on specific activities in a context of a particular lesson.

b. Micro-evaluation

Such an approach to evaluation does not accord with the perspective which many teachers have about what evaluation involves. Teachers are concerned with whether they are able to accomplish the goals or not. They do not focus on the entire program but they more focus on specific activities and techniques appearing to 'work' in the context of a particular lesson in the classroom (Ellis, 1998: 218). A microevaluation is an evaluation characterized by a narrow-focus on some specific aspect of the curriculum. Therefore, it is possible to scrutinize whether a particular task is effective or efficient not (Ellis, 1998: 219).

In a micro-evaluation, the teacher selects one particular teaching task in which he or she has a special interest, and submits this to a detailed empirical evaluation. One way in which an empirical evaluation can be made more manageable is through micro-evaluation (Ellis, 1997: 37). A micro-evaluation of teaching materials is perhaps best carried out in relation to 'task' (Ellis, 1997: 38). A micro-evaluation of a task can serve several purposes. It can show to what extent a task works for a particular group of learners. It can also reveal weaknesses in the design of a task, and thus ways in which it might be improved (Ellis, 1997: 41).

The writer tends to agree the second model of the empirical evaluation of English coursebooks, micro-evaluation. It deeply scrutinizes the elements of a certain task or teaching material in the English coursebooks. It means that the detail analysis can be possibly presented because of the length of time available. 
Two ways of analysing the data are possible. One involves quantification of the information, which can then be presented in the form of tables. The other is qualitative. Here the evaluator prepares a narrative description of the information, perhaps illustrated by quotations or protocols. In part, the method chosen will depend on the types of information which have been collected. Thus, test scores lend themselves to a quantitative analysis, while joumal data is perhaps best handled qualitatively (Ellis, 1997: 40).

\section{E. Criteria for empirical English coursebook (task) evaluation}

To judge good criteria for empirical-English coursebook evaluation is a hard job. Good criteria for English coursebooks consisting of teaching materials in the form of tasks will vary from a certain school to other schools. It happens because each school in a certain region has its own characteristics, especially its students' socio-economic backgrounds which will give impacts in other aspects. However, a number of ELT experts give clues or guide lines for coursebook evaluation.

Classroom activities should parallel the 'real word' as closely as possible. Since language is a tool of communication, methods and materials should concentrate on the massage, not the medium (Clarke \& Silberstein in Nunan, 1993: 63). Related to tasks, Widdowson in Nunan (1993) tasks must be problem-solving.

... What is wanted is a methodology which will ... provide communicative competence by function investment. Such a methodology would engage the leamers in problem-solving tasks as purposeful activities but without the rehearsal requirement that they should be realistic or 'authentic' as natural social behavior (Widdowson in Nunan, 1993:63).

It means that the tasks should be authentic as natural social behavior. Natural social behavior refers to what the students do in real life. The tasks must be suitable with the students' socio-economic cultural backgrounds.

Robinett (1978) in Brown (2001: 142), (Ellis, 1997: 39), Tucker (1975) in Ansary and Babaii (2002), Harmer (2001: 301), Reinders and Lewis (2006: 274), Spratt, Pulverness, and Williams (2005: 110), Mashura (1998: 240-241), and Nunan (2004: 174) give a practical set of criteria for evaluating a coursebook. It 
includes goals, students' backgrounds (topics and vocabulary related to students' lives), cultural acceptability, language skills to develop, quality of practical materials in the classroom (activating students' participation), roles, sequencing of the materials (procedure), formats, instructions, and visualization. Those criteria should match the students' characteristics.

Goals of the tasks are related to language skills to develop. They refer to what the students expect to learn when they use the tasks. Students' backgrounds are related to cultural acceptability. Whether the content of the tasks or coursebooks are suitable with the students are concerning with these criteria. Quality of practical materials refer to whether the tasks are able to encourage the students to participate the class or not. Sequencing of the materials refers to whether the students are easily able to follow the content of the tasks or not. Formats are related to the students' preferences on the lay out of the tasks. Instructions are related to whether the students are able to comprehend the instructions of the tasks or not. While last one, visualization refers to whether the tasks are attractive for the students or not.

The basis for such an evaluation is that a task can only be said to have worked if the students have found it enjoyable and/or useful. Evaluations conducted by means of short questionnaires or interviews with the students are the easiest kind to carry out. Response-based evaluations require the teacher to examine the actual outcomes (both the products and processes of the task) to see whether they match the predicted outcomes (Ellis, 1997:39).

Furthermore, Breen and Kumaravadivelu in Stewart (2007: 265) state that because of the influence of learners on lesson outcomes, task-based pedagogy success should be measured through the 'degree to which teacher intentions and learner interpretation of a given task converge'. In conclusion, whether the English coursebooks consisting of English teaching materials in the form of tasks are suitable or not with the English teachers, students, and environments depends on what English teachers and students' point of views when the tasks are used in the - classroom during the teaching-leaming process. 
A Summary of Criteria for a Coursebook Evaluation

\begin{tabular}{|c|c|c|c|c|c|c|c|c|}
\hline $\begin{array}{l}\text { Experts } \\
\text { Criteria }\end{array}$ & $\begin{array}{l}\text { Robi } \\
\text { net }\end{array}$ & $\begin{array}{l}\text { Alder } \\
\text { son } \\
\text { in } \\
\text { Ellis }\end{array}$ & $\begin{array}{l}\text { Tuc } \\
\text { ker }\end{array}$ & $\begin{array}{l}\text { Harm } \\
\text { er }\end{array}$ & $\begin{array}{l}\text { Reider } \\
\text { s \& } \\
\text { Lewis }\end{array}$ & $\begin{array}{l}\text { Spratt, } \\
\text { Pulvern } \\
\text { ess, } \\
\text { William } \\
\text { s }\end{array}$ & $\begin{array}{l}\text { Mash } \\
\text { ura }\end{array}$ & $\begin{array}{l}\text { Nun } \\
\text { an }\end{array}$ \\
\hline Goals & $\mathrm{V}$ & $\overline{\mathrm{V}}$ & & & & & $\mathrm{V}$ & $\mathrm{V}$ \\
\hline Approach & $\bar{V}$ & $\overline{\mathrm{V}}$ & $\mathrm{V}$ & $\mathrm{V}$ & & & & \\
\hline $\begin{array}{l}\text { Students' } \\
\text { background }\end{array}$ & V & & $\mathrm{V}$ & . $\mathrm{V}$ & & $\mathrm{V}$ & V & $\mathrm{V}$ \\
\hline Language skills & $\mathrm{V}$ & & $\mathrm{V}$ & $\mathrm{V}$ & $\mathrm{V}$ & $\mathrm{V}$ & V & $\mathrm{V}$ \\
\hline Material content & V & V & & V & V & V & V & $\mathrm{V}$ \\
\hline $\begin{array}{l}\text { Students' } \\
\text { participation }\end{array}$ & & & & & & & & $\overline{\mathrm{V}}$ \\
\hline Roles & & & & & & & & $\mathrm{V}$ \\
\hline $\begin{array}{l}\text { Sequencing/org } \\
\text { anization }\end{array}$ & V & & & $\bar{V}$ & & $\bar{V}$ & & $\mathrm{~V}$ \\
\hline Format & $\mathrm{V}$ & & & $\mathrm{V}$ & & & & \\
\hline instructions & & & & $\bar{V}$ & $\mathrm{~V}$ & & & \\
\hline Visualization & & & $\mathrm{V}$ & V & $\mathrm{V}$ & $\bar{V}$ & & \\
\hline Timing & & $\mathrm{V}$ & & & & & & \\
\hline Example & & & & & $\mathrm{V}$ & & & \\
\hline Exercise & & & & & $\mathrm{V}$ & & & \\
\hline
\end{tabular}

\section{F. Conclusion}

Considering that English teaching materials in the form of English coursebooks are one of the main elements determining the success of the English teaching-learning process, the English teachers must be selective in using such English coursebooks. They must be suitable with the students' socio-economic cultural backgrounds environments so that they can give the students meaningful inputs and meaningful learning experience. As a result, the students will optimally reach the pre-determined objectives, having communicative and pragmatic competencies. 
To find out suitable English coursebook giving meaningful inputs to the $\therefore$ students, and to be used in the following terms, the English teachers need to do an empirical evaluation of the English coursebooks they are using, retrospective evaluation. The evaluation can be done through either macro or micro evaluation. A macro evaluation entirely evaluate the whole teaching materials in the coursebooks while a micro evaluation evaluate certain parts of the coursebooks. The tangible and practical evaluation to do is micro evaluation in which the English teachers only evaluate certain parts representing the whole content of the coursebooks. Doing such a micro evaluation, the English teachers will find out such suitable English coursebooks to facilitate the students' learning. It a wise way to choose English coursebooks to be used to optimally reach the pre-determined objectives. If the teachers of English do not find such suitable English coursebooks through their evaluation, they can add materials to or reduce the content of the coursebooks and finally they will have teachers' edition English teaching materiaIs.

\section{Bibliography}

Ansary, H. \& Babaii, E. (2002). Universal characteristics of EFL/ESL textbooks: A step towards systematic textbook evaluation. The Internet TESL Journal, Vol. VIII, No. 2, February 2002. Accessed $18^{\text {th }}$ October 2008 from hittp://itesli.org/Articles/Ansary-Textbooks/

Brown H. D. (2001). Teaching by principles: An interactive approach to language pedagogy $\left(2^{\mathrm{a}} \mathrm{Ed}\right.$.). New York: Addison Wesley Longman, Inc.

Bryd, P. (2001). Textbooks: Evaluation for selection and analysis for implementation. In Celce-Muria, M. (Ed.). Teaching English as a second or foreign language (pp. 415-427) $\left(3^{\text {th }}\right.$ Ed.). South Melbourne: Heinle\&Heinle Thomson Learning.

Council of Europe (2002). Common European framework of reference for language: Learning, teaching, assessment. Cambridge: Cambridge University Press.

Crawford, J. (2002). The role of materials in the language classroom: Finding the balance. In Richards, J. C. \& Renandya, W. A. (Eds.). Methodology in language teaching: An anthology of current practice (pp. 80-91). Cambridge: Cambridge University Press.

Depdiknas. (2003). Undang-Undang Republik Indonesia Nomor 20 Tahun 2003 tentang Sistem Pendidikan Nasional. From Legalitas.org. 
Depdiknas. (2005). Pearturan Pemerintah No. 19 Tahun 2005 tentang Standar Nasional Pendidikan. From Legalitas.org.

Depdiknas. (2006). Peraturan Menteri Pendidikan Nasional No. 22 Tahun 2006 tentang Standar Isi. From Legalitas.org.

Depdiknas. (2006). Peraturan Menteri Pendidikan Nasional No..23 Tahun 2006 tentang Standar Kompetensi Lulusan. From Legalitas.org.

Depdiknas. (2006). Peraturan Menteri Pendidikan Nasional No. 24 Tahun 2006 tentang Pelaksanaan Permen No. 22/2006 and Permen No. 23/2006. Firom Legalitas.org.

Ellis, R. (1997). The empirical evaluation of language teaching materia]s [E]ectronic Version]. ELT Journal Volume 51/I January 1997, 36-42. Accessed $18^{\text {th }}$ October 2008 from http://eltj.oxfordjournals.org.simsrad.net.ocs.mq.edu.au/cgi/reprint/51/1/36?ma xtoshow=\&HITS=10\&hits=10\&RESULTFORMAT=\&fulltext=the+empirical+ evaluation + of + language + teaching + materials \&searchid $=1 \&$ FIRSTINDEX $=0 \& \mathrm{kr}$ esourcetype $=$ HWCI.

Ellis, R. (1998). The evaluation of communicative tasks. In Thomlinson, B. (Ed). Materials development in language teaching (pp. 217-238). New York: Cambridge University Press.

Ellis, R. (2003). The study of second language acquisition. Oxford: Oxford University Press.

Harmer, J. (2001). The practice of English language teaching ( $\left({ }^{\text {rd }} \mathrm{Ed}.\right)$. Harlow: Longman. http://www.bsnp-indonesia.org/document.php?id=34 Accessed $22^{\text {ad }}$ January 2008

Johnson, K., Kim, M. \& Ya-Fang, L. et al. (2008). A ștep forward: investigating expertise in materials evaluation [Electronic Version]. ELT Journal Volume 62/2 April 2008, 157-162. Accessed I" November 2008 from http://eltj.oxfordjournals.org.simsrad.net.ocs.mg.edu.au/cgi/reprint $/ 62 / 2 / 157 ? \mathrm{~m}$ axtoshow=\&HITS=10\&hits=10\&RESULTFORMAT =\&fulltext=the+empirical tevaluation + of + language+teaching + materials\&searchid $=1$ \&FIRSTINDEX $=0$ \&resourcetype $=$ HWCIT

Littlejohn, A. (1998). The analysis of language tèaching materials: Inside the trojan horse. In Thomlinson, B. (Ed.). Materials development in language teaching (pp. 190-216). New York: Cambridge University Press. 
Mashura, H. (1998). What do teachers really want from coursebooks? In Thomlinson, B. (Ed.). Materials development in language teaching (pp. 239-260). New York: Cambridge University Press.

Murphy, D. F. (1993). Evaluating language learning tasks in the classroom. In Crookes, G. \& Gass, S. M. (Eds.). Tasks in a pedagogical context: Integrating theory and practice (139-161). Frost Road: Multi Lingual Matters LTD.

Nunan, D. (1993). Task-based syllabus design: Selecting, grading and sequencing tasks. In Crookes, $G$ \& \& Gass, S. M. (Eds.). Tasks in a pedagogical context: Integrating theory and practice (55-68). Frost Road: Multi Lingual Matters LTD.

Nunan, D. (1999). The learner-centred curriculum: $A$ study in second language teaching. Cambridge: Cambridge University Press.

Nunan, D. (2004). Task-based language teaching. Cambridge: Cambridge University Press.

Graves, K. (2003). Coursebook. In Nunan, D. (Ed.). Practical English language teaching (pp. 225-246). New York: Contemporary.

Rea-Dickins, P. \& Germaine, K. (2003). Purposes for evaluation. In Hall, D. R. \& Hewings, A. (Eds.). Innovation in English language teaching: $A$ reader (pp. 253-262). New York: Rouledge.

Reinders, H. \& Lewis, M. (2006). An evaluative checklist for self-access materials [Electronic Version]. ELT Journal Volume 60/3 July 2006,272-278. Accessed $11^{\text {th }}$ October 2008 from http://elti.oxfordjoumals.org.simsrad.net.ocs.mq.edu.au/cgi/reprint $/ 60 / 3 / 272 ? \mathrm{~m}$ axtoshow=\&HIS=10\&hits=10\&RESULTFORMAT = \& fulltext=the+empirical tevaluation +of+language+teaching+materials\&searchid=1\&FIRSTINDEX $=0$ \&resourcetype=HWCIT

Richards, J. C. (2001). Curriculum development in language teaching. Cambridge: Cambridge University Press.

Richards, J. C. \& Renandya, W. A. (2002), Methodology in language teaching: An anthology of current practice. Cambridge: Cambridge University Press.

Stewart, T. (2007). Teachers and learners evaluating course tasks together. ELT Journal 2007 61(3),256-266. Accessed $1^{\text {rt }}$ November 2008 from

http://eltj.oxfordjoumals.org.simsrad.net.ocs.mq.edu.au/cgi/content/full/61/3/256?maxto show $=$ \&HITS=10\&hits=10\&RESULTFORMAT $=$ \&fulltext=EVALUATING $+\mathrm{T}$ EACHERS $\% 27+$ GUIDE\&searchid=1\&FIRSTINDEX =0\&resourcetype-HWCI I 